Croatian International Relations Review

-

XXVI (87) 2020,

86-119

DOI 10.37173/

cirr.26.87.4

UDC 614.88:342.7:341

\section{The Challenges to the} Emergency Medical Services to be Recognised as a Human Right in International Human Rights Law

\section{Jenna Uusitalo}

Faculty of Law, University of Helsinki, Finland jenna.uusitalo@helsinki.fi

ORCID: 0000-0002-7799-7289
Key words:

Emergency Medical Services; Health Care; Human Rights; International Humanitarian Law; Peacebuilding

\section{Abstract}

The Emergency Medical Services (EMS) are emergency services generally been designed to provide urgent treatment of patients with life-threatening conditions outside medical facilities. Even though the EMS belongs to the category of socio-economic rights, it nevertheless has great significance in safeguarding one of the most fundamental human rights, the right to life. In fact, international humanitarian law has recognised this important connection by establishing explicit legal rules that oblige states to ensure urgent medical care for the wounded and sick. International human rights law, on the other hand, has no such expressed provisions. However, the problem is not the lack of legal rules applicable to the EMS as such but rather the challenges in human rights perception, which hinder the EMS being perceived as a valuable human right. Therefore, this article essentially argues that international human rights law does not recognise the EMS as a human right sufficiently and that more thorough actions are required from the UN Committee of Economic, Social and Cultural Rights (CESCR) in this regard. 


Croatian
International
Relations
Review
-
CIRR
-
XXVI (87) 2020,
$86-119$

86-119

\section{Introduction}

International law contains numerous legal provisions designed to ensure the right to health and health care. For example, international humanitarian law (IHL), regulating the conducts of warfare, provides many explicit norms concerning the urgent treatment of the sick and wounded. During peacetime, the right to health is guaranteed, inter alia, by Article 12 of the International Covenant on Economic, Social and Cultural Rights (ICESCR). Furthermore, the importance of a functioning health care system is also perceived as part of a conciliation process and a fundamental condition for peace in post-conflict states (Evert and Evans 2008: 81-82). However, despite the right to health care being recognised and applied during armed conflicts, post-war situations and peacetime, the extent of the protection and the perception of its importance seems to vary, depending on which rules of international law are applicable. In fact, it seems that health care and, in particular, emergency medical service, have great legal importance during armed conflicts but faces challenges during peacetime.

Acknowledging the wide scope of health and health care, this article focuses primarily on analysing the emergency medical service (EMS). According to the World Health Organization (WHO), the EMS consists of out-of-hospital treatment that is provided to patients with an acute illness or injury requiring urgent medical attention (WHO 2019a; WHO 2019b). While the WHO's approach to the EMS is more or less medically-oriented, from a legal perspective likeminded definition is codified, inter alia, in Article 40(1) of the Health Care Act in Finland and Article 16(1) of the Health Service Organisation Act in Estonia. Notably, the EMS is distinguished from a broader term of 'emergency medical care', which generally also includes in-hospitalpatients (WHO 2019a; Reynolds et al. 2018). While these two health care concepts can mainly be regarded as synonyms, the distinction is best demonstrated through a medical example of cardiac arrest. According to medical research, defibrillations should be started as early as possible, preferably within 3 to 5 minutes after the collapse, because each minute of delay reduces survival probabilities (Perkins et al. 2015: 83). In hospital, resuscitation can be initiated within minutes while outside hospital settings even dispatching ambulance takes some time, placing a person's life at greater risk if the cardiac arrest occurs outside the hospital. Therefore, the EMS is not 
Croatian

International

Relations

Review

$-$

CIRR

$-$

XXVI (87) 2020,

$86-119$ only an integral element of the functioning health care system but is also an essential component in safeguarding the most fundamental human rights, such as the right to life, which is protected, inter alia, in Article 6 of the International Covenant on Civil and Political Rights (ICCPR).

Notably, Article 12(2)(d) of the ICESCR urges the states to create conditions which would assure medical service and medical attention to all in the event of sickness. As the essential function of the EMS is to provide urgent medical care for acute illnesses or injuries, the present analysis already considers that Article 12(2)(d) of the ICESCR is applicable to the EMS as well as explained more thoroughly in Section three below. In turn, the legal basis for arguing that the EMS is protected under IHL lies in the Articles obliging states to provide urgent medical treatment to the wounded and sick without undue delay. This principle has been codified, inter alia, in Article 12 of the 1949 Geneva Convention I, Article 10(2) of the 1977 Additional Protocol I, and Article 7(2) of the 1977 Additional Protocol II.

Interestingly, the EMS in peacetime entails more comprehensive protection than during wartime. According to Article 8(a) of the Additional Protocol I, for instance, the wounded and the sick are defined as persons who are in need of immediate medical assistance or care because of trauma, disease or other physical or mental disorder or disability. This indicates that only the most crucial medical cases are to be treated, whereas, in peacetime, the coverage of out-of-hospital care is much broader. In Finland, for instance, situations to which the ambulances are responding vary from severe traumas to milder medical conditions such as acute deprivation of smell or vision, as well as to psychosocial help offered to the patients and their relatives (Silfvast et al. 2013: 62; Salminen-Tuomaala, M. et al. 2018: 1376). In fact, in Finland, the EMS missions are divided into four categories according to their urgency. In the most life-threatening situations, the patient should be reached preferably within 8 minutes from the dispatch, whereas in less severe cases indicated timeframe is 30 minutes or even 120 minutes (Hoikka et al. 2017: 551; STM 2017: 10-11). Moreover, medical research shows that the ambulances are increasingly receiving calls relating to non-critical situations (Paulin et al. 2020; Roivainen et al. 2020: 556; Hoikka et al. 2016). Yet, from the legal perspective, the EMS is not recognised expressly in IHRL. 


Croatian
International
Relations
Review
-
CIRR
-
XXVI (87) 2020,
$86-119$

Croatian International Relations 86-119
Regarding IHRL, it should also be noted that human rights are separated into two categories, based on the different nature of the rights. The first category includes civil and political rights, such as the right to life. Nowadays, it is widely acknowledged that the protection of civil and political rights demands active actions from states as well, as explained more thoroughly in Section five below. Yet historically, these rights have been prioritised over the socio-economic rights as the violations of first-category rights are easier to detect (Chandhoke 2007: 182; Evju 2009: 84). The protection of economic, social and cultural rights (i.e. the second category of rights), has always been identified to require active contributions and resources from states (Charvet and Kaczynska-Nay 2008: 86-87; Baderin and McCorquodale 2007: 6-12). The separation of these two human rights categories is visible in the UN Covenants in which firstcategory rights are found in the ICCPR and socio-economic rights in the ICESCR.

Moreover, this distinction seems still to prevail in state practice, even though the Vienna Declaration and the Programme of Action in 1993 stated that despite the two categories, all human rights are equal in importance (Vienna Declaration 1993; Chandhoke 2007: 191). Many human rights surveys, to give an example, have placed Finland among the leading states in protecting human rights. ${ }^{1}$ Yet, Finland seems to regard the EMS as an economic expense rather than a human right even though the Parliamentary Ombudsman has repeatedly stated that geographical dead zones in emergency medical physicians' availability are not in accordance with fundamental rights codified in the Constitution (Parliamentary Ombudsman 2015 and 2017; STM 2018). ${ }^{2}$

Consequently, the purpose of this article is to identify the challenge that the EMS faces because it belongs to the category of socio-economic right and because it has not been expressly mentioned in the human rights law. Essentially, the article argues that international human rights law does not recognise the EMS as a human right sufficiently

1 According to the 2020 World Press Freedom Index, Finland has the second free press in the world. Transparency.org has listed Finland as a third least corrupted country, and the Sustainable Development Solutions Network rates Finland as the happiest country in its survey on how happy citizens in different states perceive themselves to be.

2 The report, initiated after the Ombudsman's decision, discussed the organisational and financial structures primarily and did not refer to human rights provisions in Finland's Constitution or in any human rights treaties applied in Finland. 
Croatian

International

Relations

Review

$-$

CIRR

$-$

XXVI (87) 2020,

$86-119$ and that more thorough actions are required from the UN Committee of Economic, Social and Cultural Rights (CESCR) in this regard. To support this argument, the article analyses the legal challenges for the EMS to be recognised as a human right and how the CESCR could tackle them. For this purpose, the article reflects the UN Human Rights Covenants in terms of the legal norms applied during armed conflicts as well as in post-conflict situations as all of these legal frameworks are binding upon states. A specific focus is on the EMS, but some analysis is dedicated to health care in general in order to provide a more comprehensive overview. The aim of this article is not to provide an exhaustive answer for the CESCR to be adopted as such but rather to offer some tools and ideas for further analysis.

Lastly, this article acknowledges that IHL faces challenges in practice, especially in relation to respecting the rules, and that the provisions protecting the EMS are not an exception in this regard. In fact, the International Committee of the Red Cross (ICRC) has established position papers and recommendations aiming to enhance and strengthen the protection of health care workers during armed conflicts (ICRC 2014; ICRC 2016). However, it is not the aim of this article to engage in an analysis of such challenges but simply to recognise the precise scope of the Geneva Conventions in terms of protecting the EMS. It is equally noted that IHL does not provide any further guidance on the quality or quantity of health-care service (Breitegger 2013: 95). However, this aspect is not relevant for this article as a leading argument is that a legal provision on urgent out-of-hospital medical care has been codified in IHL. In contrast, they are absent from international human rights law (IHRL). The main analysis, therefore, focuses on the practical challenges of guaranteeing and protecting emergency medical services outside armed conflicts.

The article is structured as follows: after the introduction, Section two briefly explains the legal basis for the EMS under IHL and IHRL. The main discussion regarding the challenges of recognising the EMS as a human right under international law is presented in Sections three to five. Section six summarises the findings and draws conclusions. 


Croatian
International
Relations
Review
-
CIRR
-
XXVI (87) 2020,
86-119

86-119

\section{Legal grounds of the EMS - from jus in bello to full peace}

According to traditional understanding, IHRL is generally applicable during peacetime and is replaced by the rules of IHL during armed conflicts (Müller 2013: 4). However, a modern perception emphasises a more complementary application of both, according to which IHRL and IHL cannot be distinguished from one other completely during wartime (IJC 1996: 25; Müller 2013: 14-15; Lubell and Prud'homme 2016: 107). Nevertheless, despite the contemporary approach, IHL and IHRL have essentially been developed to guarantee relatively different levels of protection for individuals in entirely different situations. While IHRL is generally regarded as having originated from the establishment of the Universal Declaration of Human Rights (UDHR) in 1948, rules regulating the means and methods of warfare have existed for centuries or even millennia (Martin 2006: 335; Greenwood 2006: 784). In addition to customary rules and bilateral treaties, the first multilateral documents codifying the norms of armed conflicts began to emerge in the $19^{\text {th }}$ century (Roberts and Cuelff 2010: 4-5). ${ }^{3}$

The EMS has always been at the heart of jus in bello rules either explicitly or implicitly. Article 2 of the 1864 Geneva Convention relating to the wounded and the sick, being one of the first binding international documents in terms of wartime laws, already acknowledged the importance of protecting ambulances and medical personnel. Currently, the most prevailing provisions, explicitly safeguarding the integrity of mobile medical units, can be found, inter alia, in Article 19 of the 1949 Geneva Convention I, Article 12(1) of the 1977 Additional Protocol I and Article 11(1) of the 1977 Additional Protocol II. ${ }^{4}$ Moreover, while the rules of armed conflict do not have explicit legal provisions stating that the EMS shall be provided for the injured, this ideology can be interpreted from the spirit of IHL seeking to ensure urgent medical treatment of the wounded and the sick. Article 12 of the 1949 Geneva Convention I, for

3 These are, for example, the 1856 Paris Declaration on maritime war, generally regarded as being the first international treaty regulating armed conflicts, followed by the 1864 Geneva Convention relating to the wounded and the sick and the 1868 St. Petersburg Declaration on explosive projectiles.

4 The full titles of these documents are the Geneva Convention (I) for the Amelioration of the Condition of the Wounded and Sick in Armed Forces in the Field. Geneva, 12 August 1949; Protocol Additional to the Geneva Conventions of 12 August 1949, and relating to the Protection of Victims of International Armed Conflicts (Protocol I), 8 June 1977; Protocol Additional to the Geneva Conventions of 12 August 1949, and Relating to the Protection of Victims of Non-International Armed Conflicts (Protocol II), 8 June 1977. 
Croatian

International

Relations

Review

$-$

CIRR

$-$

XXVI (87) 2020,

$86-119$ example, states that "only urgent medical reason will authorise priority in the order of treatment to be administrated." Identical wording in Article 10(2) of the 1977 Additional Protocol I and Article 7(2) of the 1977 Additional Protocol II, on the other hand, stipulates that medical care must be provided with the least possible delay.

The application of jus in bello rules generally becomes redundant when peace is achieved. However, very rarely does the transformation from hostilities to full peace occur automatically. Instead, certain interphases, such as peacekeeping or peacebuilding, are required. During these stages, the legal framework for the EMS is already more difficult to interpret than during ongoing conflicts.

Notably, international law does not provide a direct legal basis or definition for peacekeeping or peacebuilding operations. The concept of peacekeeping emerged during the Cold War because of the impasse of the United Nations (UN) Security Council, and with the purpose of assembling independent forces to pursue collective security by keeping two conflicting sides apart (Nye 2005: 171-172; Ramcharan 2008: 138; White 2015). Peacebuilding, on the other hand, is most commonly defined as "promoting sustainable peace by addressing the root causes of violent conflict and supporting indigenous capabilities for peace managing" (UN 2010: 5). Therefore, the general legal foundation for both concepts can be found in the UN Charter, Articles 55 and 56, which perceive the conditions of stability and wellbeing as necessary for peace and pledge all states to take joint and separate actions to achieve such conditions.

Due to the absence of expressed legal rules, designed specifically to peacekeeping and peacebuilding, the protection of the EMS in transitional states emerges from the general legal provisions of IHRL. Peacekeeping and peacebuilding operations can, of course, be occasionally initiated while the conflict is still ongoing, however, as a general rule, the troops are usually sent in a post jus in bello environment, stipulating the applicability of IHRL rules (UN 2008: 19; ICJ 2004; Bethlehem 2013). The application of IHRL in fully stable states and countries recovering from armed conflicts cannot, however, be regarded as similar.

Under "normal" circumstances, the protection of (first-category) human rights is an internal matter of the state, and other states 


Croatian
International
Relations
Review
-
CIRR
-
XXVI (87) 2020,
$86-119$

\section{Croatian}

International

Relations

$86-119$ are restricted from any intervention under Articles 2(1) and 2(4) of the UN Charter. On the other hand, because of its supporting role in peacekeeping and peacebuilding operations, and based on Articles 55 and 56 of the UN Charter, the international community is de facto engaging in promoting and protecting human rights within the territory of another state in a postconflict situation. Furthermore, Article 2(1) of the ICESCR recognises the mandate for international assistance and cooperation in relation to economic, social and cultural rights, ${ }^{5}$ and is equally applicable in post-conflict situations and within peaceful states. Such a transnational human rights effect is discernible in relation to socio-economic rights through, for example, development assistance (Skogly and Gibney 2002: 784; Woodward 2000).

Moreover, the essential purpose of post-conflict management - especially peacebuilding - is to prevent future conflicts not only by creating stability through the promotion and implementation of the rule of law, democracy and respect for human rights but also through the strengthening of institutional structures and the creation of internal security (Ramcharan 2008: 165-166; Bellamy and Williams 2015; CahillRipley 2016: 226). In other words, one of the basic principles in a post-conflict situation is the assistance provided by the international community in building up a state that can ensure sustainable safety for individuals at all levels, including health care.

Similar to transitional states, the protection of human rights in peacetime is primarily guaranteed by the ICCPR and ICESCR which have, in fact, been highly endorsed, as nearly 170 states have ratified them (OHCHR 2020). Naturally, the EMS is not expressly referred to in either of these documents. Admittedly, protection can be implied from Article 12(1) of the ICESCR, which guarantees the right of everyone to the highest attainable standards of physical and mental health. Article 12(2)(d), on the other hand, obliges the contracting states to take steps to realise the creation of conditions ensuring access to medical service and medical attention for all in the event of

5 Art. 2(1) of ICESCR states that "Each State Party to the present Covenant undertakes to take steps, individually and through international assistance and co-operation, especially economic and technical, to the maximum of its available resources, with a view to achieving progressively the full realisation of the rights recognised in the present Covenant by all appropriate means, including particularly the adoption of legislative measures." 
Croatian

International

Relations

Review

$-$

CIRR

$-$

XXVI (87) 2020,

$86-119$ sickness. General Comment No. 14, drafted by the Committee of the Economic, Social and Cultural Rights (CESCR) to clarify the scope of Article 12 of the ICESCR, is often perceived as a basis for the interpretation of how the right to health should be understood (CESCR 2000; Hunt 2016). Read and applied in conjunction with General Comment No. 3, which clarifies the general obligations of states under the ICESC, General Comment No. 14 establishes valuable guidelines highlighting the states' obligations regarding the right to health (CESCR 2000: 30-32; CESCR 1991: 10). However, the fact that the General Comment No. 14 does not specifically mention the EMS can be regarded as one factor in explaining why urgent out-of-hospital medical care faces challenges in striving to be perceived as a human right.

\section{Challenges in identifying universal standards for the EMS}

Since the essence of the EMS has been defined as providing urgent treatment for the sick and injured, the EMS reflects de facto the same principle of humanity which IHL has been designed to protect in all circumstances during armed conflicts. In other words, IHL recognises the EMS as an essential element for safeguarding the right to life by codifying expressed provisions relating to the integrity of ambulances in Article 19 of the 1949 Geneva Convention I and emphasising urgent treatment in Articles 10(2) of the Additional Protocol I and 7(2) of Protocol II.

Regarding post-conflict situations, the impact of conflicts causing various health problems, such as famine, the lack of proper sanitation and shortage of medical supplies, has also been widely acknowledged (Santa Barbara 2008: 120; Gutlove 2007: 8; Toabes 2015: 488-504). Equally, it is understood that failure to guarantee the social well-being of individuals as such, can compromise the whole peace process (Cahill-Ripley 2016: 225; Niemelä 2008: 102). According to the same logic, the failure to guarantee a properly functioning and accessible EMS undermines the main goals of peacebuilding aiming to create a safe environment for the individuals to live their daily lives.

A survey shows that properly functioning and accessible emergency care is perceived as one of the critical elements of primary health care also in developing countries. Still, the lack of emergency medical transport is a common barrier 


Croatian
International
Relations
Review
-
CIRR
-
XXVI (87) 2020,
$86-119$

Croatian International Relations $86-119$ to accessibility, especially in the most life-threatening situations (Razzak and Kellermann 2002: 901; Kobusingye 2005: 629). According to the studies, the availability of the EMS causes a $25 \%$ reduction in trauma-related mortality alone, simultaneously indicating that the effective EMS system is an important component in preventing deaths caused by injuries or the sudden onset of illness (Mehmood et al. 2018; Kobusingye 2005: 627). Equally, an analysis from Latin America illustrates that an increase in the number of ambulances and trauma training offered to the ambulance crew reduces the number of deaths during transport (Razzak and Kellermann 2002: 901; Arreola-Risa et al. 2000: 119-124). Therefore, the EMS, serving as the first link in the health care chain, has great significance not only in developing states. It should also be recognised as one of the first requirements that need to be guaranteed when peace processes are initiated after violent conflicts.

However, out-of-hospital care outside armed conflict is highly prone to legal shortcomings. A prevailing challenge is caused by the lack of harmonised guidelines under international law because the EMS is neither expressly codified in the ICESCR, nor is it referred to in any of the General Comments. Notably, General Comment No. 14 does shed some light on the concept of and the basic requirements for a minimum level of health care, inter alia, by introducing the so-called AAAQ framework, which stands for availability, accessibility, acceptability and quality (CESCR 2000: 12). This framework can be applied to the EMS as well.

In general, availability obliges states to ensure that functioning public health and health-care facilities, goods and services are available in sufficient quantity within their territories (CESCR 2000: 12(a)). While the precise nature of this obligation can vary depending on numerous factors- such as the states' development level - hospitals, clinics, health-related buildings, and trained medical staff are, nonetheless, among the underlying determinants for availability (CESCR 2000: 12(a); Special Rapporteur 2013: 23). In the EMS context, availability requires, inter alia, the guarantee of a sufficient number of adequately equipped ambulances with a trained staff that can respond to medical emergencies throughout the states' territories (Burkholder, Hill, and Calvello Hynesc 2019: 613; WHO 2019a). 
Croatian

International

Relations

Review

$-$

CIRR

$-$

XXVI (87) 2020,

$86-119$

Accessibility, on the other hand, requires health facilities, goods and services to be accessible to everyone without discrimination. The said refers equally to non-discrimination among different groups, to physical accessibility as regards the location of the facilities, to affordability, and the accessibility of information regarding health (CESCR 2000: 12(b); MacNaughton and Hunt, 2009: 303; Buer Haddeland 2019: 334). Regarding the EMS, the accessibility consists of, at the very minimum, specific evaluations on how to locate the ambulances to optimise their usage but simultaneously to ensure timely emergency care in sparsely populated areas as well.

Acceptability means that health facilities, goods and services must respect medical ethics and cultural specifications (CESCR 2000: 12(c); Hunt and Backman 2008: 83). The quality requirement includes, inter alia, skilled medical professionals, suitable medical equipment, as well as scientifically and medically appropriate services (CESCR 2000: 12(d); Hunt 2007: 370-371). Consequently, acceptability and quality are somewhat intertwined, as properly educated ambulance crew should not only be expected to know applicable medical procedures but also to respect patients.

Furthermore, General Comment No. 14 establishes core obligations that all states should fulfil immediately to ensure the very minimum level of primary health care. In relation to the EMS, these include access to health facilities, goods and services without discrimination; the provision of drugs which are considered essential; the equitable distribution of health facilities, goods and services; and the adoption and implementation of a national public health strategy and the plan of action to address health concerns of the whole population (CESCR 2000: 43; Burkholder, Hill, and Calvello Hynesc 2019: 614). ${ }^{6}$ In essence, these core obligations amplify the AAAQ framework in many ways. The access to and equitable distribution of services are attributable to availability and accessibility reflecting on how to locate the ambulances and ensure their timely availability throughout the state. Essential drugs, on the other hand, form a sub-category to quality as proper medicines are a vital part of medically and scientifically

6 Notably, other core obligations defined in the General Comment No. 14, which nevertheless are not directly applicable to the EMS, refer to access to essential food, and access to shelter and sanitation (CESCR 2000: 43.; Burkholder, Hill, and Calvello Hynes 2019.). 


Croatian
International
Relations
Review
-
CIRR
-
XXVI (87) 2020,
$86-119$

Croatian International Relations 86-119 appropriate treatments. Finally, public health strategy offers a comprehensive layout on how states strive to fulfil the obligations under Article 12(2)(d) of the ICESCR.

Nonetheless, the AAAQ framework and core obligations pertain to the right to health at a general level. While they are applicable to the EMS as well, in the absence of an expressed indication at the international level on how the EMS should be structured, states must decide on its exact content. National legislation relating to the EMS shares, of course, certain significant similarities by referring to the out-of-hospital treatment of patients who have suffered an injury or an onset of illness, as has been demonstrated, inter alia, in Article 40(1) of Finland's Health Care Act and article 16(1) of Estonia's Health Service Organisation Act. However, roughly speaking, there can be 170 different interpretations of the ICESCR, Article 12(2)(d) in relation to the EMS, as each state can implement that Article according to its vision. It remains even disputable whether social emergencies, which nonetheless are non-medical in nature, such as loneliness, fall within or outside the scope of the EMS (Kosonen et al. 2016).

Therefore, a detailed General Comment explicitly dedicated to the EMS should be drafted in order to establish a more harmonised basis to urgent out-of-hospital medical care at the international level. To start with, in this new General Comment, availability and accessibility under the AAAQ framework, as well as the core obligations of access to and the equitable distribution of health services should indicate standards according to which ambulances should be located. Finland, for instance, has codified highly technical details in its Decree on Emergency Medical Services (585/2017) whereas the Estonian legal framework has no such indicators (Uusitalo 2018a: 392393). Ensuring harmonised availability and accessibility to the EMS would consist, for instance, of an analysis on how many ambulances per 100.000 inhabitants or in the 100-kilometre radius are needed to meet the core obligations.

The provisions on acceptability and quality, on the other hand, should establish the least minimum level of education required from ambulance crew, and what medical equipment and staff ambulances must, at the very minimum, have. The former Soviet states, for example, tend to emphasise physician-staffed ambulance whereas, in other states, such as Finland, the EMS 


Croatian
International
Relations
Review
-
CIRR
-
XXVI (87) 2020,
86-119

units are staffed by two, or even one, health care professional (Sarapuu and Lember 2015: 1033; Lai et al. 2013: 133; Uusitalo 2018a: 394). State practices also vary in relation to essential medicines used in out-of-hospital care and the extent to which ambulance crew tasks have been regulated. Estonia, for instance, has codified a specific list of medicines used in ambulances and the particular tasks of each crew member in the Estonian Decree of EMS (Kiirabibrigaadi koosseisu ja varustuse nõuded ning tööjuhend). However, Finland only indicates in its Health Care Professional Act (559/1994) that health care professionals must employ empirically justified methods in accordance with their training. Thus, the aspects of essential medicines and ambulance crew tasks should also be addressed in the EMS-specific General Comment to ensure that patients receive urgent out-of-hospital care according to more or less equal basis despite their geographical location. Finally, this new General Comment should guide states to include the EMS provisions in their national health strategies as well to ensure that also this core obligation enshrining from Article 12(2)(d) of the ICESCR is fully acknowledged in relation to the EMS as well.

Consequently, this new General Comment should be drafted at the UN level because the legal framework is already detectable from the UN Covenants and General Comment No. 14. Indeed, the $\mathrm{UN}$, as a whole, has its own deficiencies. Its processes of drafting legislation have been criticised for being too lengthy, and the scope of its mandate to be too wide (Alston 2012: 38; Warren 2007: 242). However, as explained above, almost all states in the world are parties to the ICCPR and ICESCR. In comparison to the human rights protection in Europe, for example, the European Convention on Human Rights is legally binding in 47 states, and the European Social Charter in 34 states (CoE 2020a; CoE 2020b). Moreover, neither of these documents confer the possibility to issue General Comments on the interpretation of legal Articles according to the similar standards as both the ICCPR and the ICESCR do.7 Furthermore, as the EMS falls within the scope of Article 12(2)(d) of the ICESCR, the UN Committee of Economic, Social and Cultural Rights (CESCR) is the best instance to draft

7 In fact, the European Convention on Human Rights (ECHR) allows the European Court of Human Rights only to deal with specific circumstances either through inter-state complaints in accordance with Article 33 of the ECHR, through individual complaint in accordance with Article 34 of the ECHR, or by issuing an advisory opinion as stipulated in the Protocol 16. Likewise, the European Social Charter confers the European Social Council only the rights to review the state reports under Article C in Part IV, and to evaluate collective complaints in accordance with Article D of Part IV, providing that state party has accepted such a mechanism. 


Croatian
International
Relations
Review
-
CIRR
-
XXVI (87) 2020,
$86-119$

$86-119$ this new General Comment. However, close co-operation with the Human Rights Committee, a treaty body under the ICCPR, is needed to guarantee that the crucial interconnection between the EMS and the right to life, protected in Article 6 of the ICCPR, is adequately acknowledged.

Another challenge hindering the EMS of being recognised and fully protected under IHRL relates to the question of how the connection between Article 12(2)(d) of the ICESCR and Article 6 of the ICCPR is understood. As repeatedly emphasised in this paper, the fundamental function of the EMS is to safeguard the right to life by warding off a hazard which is threatening a patient's health and life. General Comment No. 14 (CESCER 2000: 3) de facto expressly acknowledges such an intertwined connection. Implied recognition, on the other hand, can be read in General Comment No. 6, in which it is stated that the right to life should not be interpreted narrowly (HRC 1982: 1). Therefore, at least at some theoretical level, IHRL seems to understand that socio-economic rights also share a connection with civil and political rights. However, unlike General Comment No. 14 on the right to health, referring explicitly to the rights covered in the ICCPR, the Human Rights Committee's General Comment No. 6 does not expressly refer to socio-economic rights. Enhancing the connection between the EMS and the right to life by establishing a new General Comment including this matter would also strengthen the perception according to which the EMS is, in fact, an essential human right that has been fundamentally designed to safeguard life.

Finally, one challenge on drafting universal guidelines for the EMS is to find a proper balance among different states. Namely, high-income countries, such as the Scandinavian ones, have already fairly advanced health care systems, and they are engaging in thorough medical research in the EMS field (Müller 2013: 148; FinnHEMS 2020; Kerikmäe, Hamulak and Chochia 2016: 98; IPI 2013: 20). Developing and post-conflicts states, on the other hand, are more likely to face challenges in relation to health care (Kandelman et al. 2012: 98; Naicker et al 2009: 62). Therefore, the General Comment should be drafted so that, on the one hand, it would not allow more advanced states to lower their standards and, on the other hand, less-developed countries and post-conflict states would not face a too heavy burden. The following section enlightens further how these aspects should be ensured. 


\section{Croatian \\ International \\ Relations \\ Review \\ - \\ CIRR \\ - \\ XXVI (87) 2020, \\ 86-119}

\section{Challenges caused by resources and political will}

One of the key aspects of economic, social and cultural rights is that they cannot be guaranteed all at once. States must take steps and use the maximum of available resources to achieve the full realisation of these rights progressively (Roth 2007: 171-172). However, these obligations, codified in Article 2(1) of the ICESCR, impose a further challenge for the EMS to become recognised as a human right both in post-conflict situations and in peaceful states.

To start with, Article 2(1) of the ICESCR does not only require states to enact legislation and, for instance, financially support out-of-hospital care but also obliges them to engage in wider administrative and educational activities (CESCR 1990: 7). These measures include, inter alia, the establishments of national health plans and strategies, and ensuring proper education for health care workers - being de facto attributable to the AAAQ framework and the core obligations under Article 12 of the ICESCR (Hunt and Backman 2008: 84; Hunt, P. 2007: 370-371). Nonetheless, a new General Comment should also explicitly recognise this connection between Articles 12 and 2(1) of the ICESCR to give broader importance to the commentary as a whole.

The progressive realisation, on the other hand, refers to an intent according to which states would do their very best by using the maximum of the available resources to move as expeditiously and effectively as possible towards the full realisation of the rights covered in the ICESCR (CESCR 1990: 9-11; CESCR 2000: 31; Roth 2007: 173-174). Therefore, it is not sufficient merely to establish the very minimum EMS conditions states need to fulfil under Article 12(2)(d) of the ICESCR. Instead, the General Comment should also establish an exemplary list on how states should progressively proceed once the minimum standards are met.

This list could, for instance, oblige states to evaluate their EMS systems on a yearly basis to ensure that progressive realisations of the AAAQ framework and the core obligations are, at least, considered. More thoroughly, the periodical evaluations should assess, inter alia, whether availability and accessibility could be enhanced by increasing the number of ambulances, or by 


Croatian
International
Relations
Review
-
CIRR
-
XXVI (87) 2020,
$86-119$

relocating them to meet demands better (Uusitalo 2018c: 54-56 and 62-65). Additional consideration could be given to the questions of how public information regarding the access to the EMS could be advanced, and whether the costs caused by urgent out-of-hospital treatment of patients could be reduced to promote affordability (MacNaughton and Hunt, 2009: 303; Buer Haddeland 2019: 334).

In relation to acceptability and quality, states should ensure that additional training for ambulance crew is available to maintain and enhance their level of professionalism. An analysis of patient injury reports and complaints to health care supervisory authorities could enlighten potential quality deficiencies further (Kuisma et al. 2019: 15-16). Likewise, the systematic analysis should include the medical equipment and essential medicines used in the ambulances and the need to update, renew or expand them to ensure that quality required under the AAAQ framework and the core obligation of essential medicines are noted (Burkholder, Hill, and Calvello Hynesc 2019: 614). The obligation to update the national health strategy to comply with completed annual evaluation on the EMS would ensure that the core obligation of publishing national health strategy is duly connected to obligations under Article 2(1) of the ICESCR as well (Burkholder, Hill, and Calvello Hynesc 2019: 614).

Moreover, the obligation of states to use the maximum of available resources to achieve the realisation of the rights in the ICESCR progressively also includes a strong presumption that the already acquired level of protection should, at the very least, be upheld (CESCR 2000: 32). Indeed, deliberately retrogressive measures can be adopted only after detailed consideration and in the context of the full use of the maximum available resources (CESCR 1990: 9). Nonetheless, the full scope of such requirement remains unclear. To give an example, the Administrative Court in Finland did not find violations in its case where the Hospital District removed two ambulances from rural, but populated areas (Administrative Court of Oulu 2014). The Hospital District's decision, upheld by the Court, located the closest ambulances in the city centre nearly 100 kilometres away, thus making it impossible to reach these rural areas within 8 minutes, which is the indicated timeframe in Finland for the ambulance to reach the patient in the most urgent 
Croatian

International

Relations

Review

-

CIRR

XXVI (87) 2020,

$86-119$ medical cases. ${ }^{8}$ Therefore, the new General Comment should also oblige states to include specific reasoning in national health strategy if progressive steps in relation to the EMS are not taken.

Notably, though, it is a well-known fact that the realisation of socio-economic rights requires financial, as well as technical resources and expertise which need to be used effectively both in the peace processes and in a fully stable states (Spear 2000: 146; Woodward 2000: 183). It has equally been noted that maintaining properly functioning health care system is costly and that the costs are rapidly increasing, even in economically stable states (Gilbert, Wen and Pines 2017: 39; Hoffman and Mancini 2017:361). Yet, while insufficient resources can be raised as an excuse for not meeting the obligations under the ICESCR (Zaidi 2010:125-126), such a justification appears questionable in relation to the EMS. Indeed, the failure to guarantee emergency care does not only compromise the progressive realisation required to fulfil the obligations of the ICESCR Article 12(2)(d) but can also be seen as endangering the enjoyment of the right to life, guaranteed by Article 6 of the ICCPR. Unlike Article 2(1) of the ICESCR, Article 2(1) of the ICCPR does not allow states to take progressive steps towards the realisation of the rights, but merely requires that the rights, recognised in the Covenant, are respected. Furthermore, as stipulated in Article 4(2) of the ICCPR, the right to life is among those rights that cannot be derogated from under any circumstances. The said indicates a high level of respect towards its importance and follows the likeminded logic of IHL, which seeks to protect life by adhering to specific rules that, inter alia, prohibit attacks against civilians. ${ }^{9}$

However, even though the importance of the EMS may have been acknowledged, by connecting it to Article 6 of the ICCPR, a further challenge, especially in a post-conflict situation, could relate to the mere fact that violent conflicts have a negative impact on state economies (Woodward 2000: 184). Therefore, when comparing states that are not overcoming hostilities,

8 Notably, the EMS legislation in Finland does not require that every patient is reached within 8 minutes even in the most urgent medical situations but rather obliges the hospital districts to organise out-of-hospital care so that most of population would receive the medical help within the indicated timeframes that are based on medical research findings.

9 These specific prohibitions are found, inter alia, in Article 51(2) of the Additional Protocol I and Article 13(2) of the Additional Protocol II stating that civilians shall not be the object of attack. 


Croatian
International
Relations
Review
-
CIRR
-
XXVI (87) 2020,
$86-119$

86-119 transitional regimes may simply not have sufficient financial resources to fulfil the obligations international Human Rights Covenants impose on them. In order to avoid such situations, Article 2(1) of the ICESCR expressly calls for international assistance and co-operation.

The precise understanding of what is meant by international assistance and co-operation in Article 2(1) of the ICESCR is, however, somewhat unclear. As states, first and foremost, have an obligation to their citizens, it is questionable to what extent should states provide international (financial) assistance without compromising the obligations towards their citizens (Uusitalo 2018b: 97). Article 2(1) of the ICESCR also obliges the developing states to strive to ensure the widest possible enjoyment of the right under the existing circumstances and to contribute to international co-operation and assistance (CESCR 1990, para 11-12). However, the General Comment No. 3, which clarifies the state obligations under Article 2(1) of the ICESCR, emphasises explicitly that international cooperation for development is an obligation of all states, but particularly incumbent upon those states that have the ability to assist other states (CESCR 1990, para 14). This indicates not only the obligation to provide international assistance but also the right to request it in cases where the state's resources are not sufficient. However, in the absence of specific guidelines regarding the minimum standards of the EMS, it remains unclear when states can de facto ask for international assistance. Consequently, the General Comment on the EMS would also clarify the scope of international assistance because states would have a clearer understanding of what is required by them to ensure the EMS.

Ultimately, international assistance or progressive realisation are not the questions of the existence of de jure obligations but are linked to political will and values as well. When all states have economic expenses to cover, international assistance, as well as the progressive realisation of socio-economic human rights, become subjects to politics (Frankenberg 2012: 36 and 50; Easley, Marks and Morgan Jr. 2001: 1922-1925). This scheme does not merely emerge in post-war situations but is also visible in highly developed states.

The implementation of human rights still seems to be affiliated with a historical misunderstanding that the progressive realisation of socio-economic rights in the ICESCR, such as 


\section{Croatian \\ International \\ Relations \\ Review \\ $-$ \\ CIRR \\ $-$ \\ XXVI (87) 2020, \\ $86-119$}

health care, requires resources and higher contributions on the part of the state in comparison to civil and political rights (Chandhoke 2007: 182). In reality, all human rights require continuous resources (Skogly 2012: 395). To give an example, the right to a fair trial cannot be achieved unless the judges are trained to understand and apply, inter alia, the essential principles of criminal law such as the presumption of innocence under Article 14(2) of the ICCPR, and the prohibition of ex post facto laws under Article 15(1) of the aforementioned Covenant.

Furthermore, General Comment No. 6 of the Human Rights Committee, dealing with the most fundamental human right to life, obliges states to take preventative actions in relation to criminal acts aimed at taking one's life (HRC 1984: 3). Representing a more or less traditional and somewhat oldfashioned perception, according to which the right to life and the deprivation of life are associated with criminal actions, there is no valid reason why a state should not be compelled to maintain a functional EMS system. The failure of any state to provide a sufficient number of ambulances to accommodate the needs of the population is likely to cause unnecessary loss of life contrary to Article 6 of the ICCPR (Uusitalo 2018c: 5456). Therefore, civil and political rights are not exempt from economic evaluation either and do not operate independently of socio-economic rights.

Moreover, the challenge of dividing the resources between different human rights to ensure progressive realisation, or to provide international assistance, may not derive from the resources per se but from political considerations and the fact that some rights are more attractive than others, without necessarily reflecting upon the seriousness of the right (Kerikmäe and Nyman-Metcalf 2012: 47; MacDougall 2017: 136). The right to education, for example, is a right which concerns every family with children, whereas individuals can live their whole lives without needing to call for an ambulance. It is, therefore, understandable that a politician seeking to gain votes in an election would rather promote free elementary education for all children than utilise direct state resources to maintain expensive emergency services the majority of the population may never need. Equally, individuals may be more likely to vote for a candidate who supports the realisation of rights that are present in the daily lives of all individuals (Albarello, Crisp and Rubini 2018: 317; Montgomery 2020: 373). Thus, the right to 


Croatian
International
Relations
Review
-
CIRR
-
XXVI (87) 2020,
$86-119$

Croatian International Relations $86-119$ education may prevail over the EMS despite the fact that failure to guarantee equal access to primary education can hardly be associated with a potential violation of the right to life under Article 6 of the ICCPR.

Further consideration should be given to the fact that the ICCPR and the ICESCR represent a comprehensive list of numerous different rights which require different contributions. As all rights are regarded as being of equal importance, states cannot direct all available resources to the EMS, even when correctly functioning emergency care is perceived as an essential element of safeguarding the most fundamental right to life. Instead, a balance must be sought between the EMS and other rights (Young 2008: 128; Vienna Declaration 1993). It follows that, even without any political motivations, the state is obliged to consider a wide range of institutions, including police forces, the court system, social security, care for the elderly and primary education to name just a few examples, while drafting budgets and directing resources to human rights. Therefore, certain rights, such as the right to participate in cultural life for example, which seem irrelevant in post-war situations, should be guaranteed at least to some extent (CESCR 2020; Chandhoke 2007: 193). Consequently, instead of aiming to achieve the full realisation of one specific right, like the EMS under Article 12(2)(d) of the ICESCR, the state may distribute the resources among several rights, in which case none of these rights is fully protected, however, no right is left without any protection. Thus, the General Comment on the EMS would establish basic guarantees for the EMS not to be entirely overlooked in these political processes.

Consequently, the new General Comment on the EMS should not only indicate the minimum acceptable level of the EMS under Article 12(2)(d) of the ICESCR but also connect it to the ICESCR, Article 2(1). Harmonised, international EMS standards, comprehensively taking also progressive realisation into account, the usage of available resources as well as international co-operation and assistance, would not only complement the equality of human beings worldwide but would also facilitate the identification of states which are not fulfilling their obligations to ensure urgent out-of-hospital medical care. The following section enlightens some of the challenges relating to the enforcement of the right to the EMS. 


\section{Croatian \\ International \\ Challenges regarding enforcement in domestic courts}

Relations

Review

-

CIRR

$-$

XXVI (87) 2020,

$86-119$

A legal rule, however, regardless of how it may have been devised and for whatever purpose it has been formulated, has little importance without an effective enforcement mechanism to ensure compliance. In this regard, IHL ensures comprehensive and unequivocal judicial provisions in situations in which the rules of armed conflicts have been violated, as the Geneva Conventions criminalise grave breaches of the Conventions and oblige all states to pursue criminal proceedings at the national level. ${ }^{10}$ Article 86 of the Additional Protocol I, for instance, obliges states to take necessary measures to suppress all breaches of the Geneva Conventions or the Additional Protocol I, and in case of violation, to pay compensation in accordance with Article 91 of the Protocol. Consequently, as Article 10(2) of the Additional Protocol I requires medical care to be offered without undue delays, failure to provide adequate out-of-hospital care represents a violation of IHL.

Furthermore, as grave breaches of the Geneva Conventions constitute international crimes with universal jurisdiction and non-applicability of statutory limitations, the inability or unwillingness to prosecute on the part of one state, does not grant acquittal to the perpetrator but in fact, shifts the responsibility of enforcement to other states (Zyber 2018: 3; Broomhill 2003: 106-107). Such a strong obligation of enforcement not only acts as a deterrent by seeking to prevent future attacks against medical institutions and ambulances but also emphasises the importance of the EMS and health care in general.

While IHL invokes only individual criminal liability in limited cases and, therefore, does not offer that much of an individual remedy for the victims who have not received urgent outof-hospital care during wartime, the enforcement of the jus in bello rules, nevertheless, reflects robust international

10 Legal bases are found, inter alia, in Articles 49 to 54 of the Geneva Convention I; Articles 50 to 53 of the Convention II; Articles 129 to 132 of the Convention III; Articles 146 to 149 of the Convention IV; Articles 85 to 91 of the Additional Protocol I. Notably though, the Additional Protocol II does not include such Articles, although the Protocol II shares similar Articles with the Protocol I on prohibiting the attacks against civilians and ensuring urgent medical treatment. As the Additional Protocol II is applicable to non-international armed conflicts, the violation of the provisions in that Protocol are subject, first and for most, to national proceedings. Notwithstanding, states may choose to exercise universal jurisdiction emerging from customary international law also in relation to the Additional Protocol II (Zyber 2018: 5; ICRC 2003). 


Croatian
International
Relations
Review
-
CIRR
-
XXVI (87) 2020,
$86-119$

Croatian

International

Relations

$86-119$

protection by obliging states to pursue legal proceedings. IHRL, on the other hand, offers grounds for individuals to seek justice, but the enforcement is affiliated with some challenges. To start with, IHRL and socio-economic rights, in particular, have been criticised for being too imprecise and lacking sufficient measures for coercing the offending state into meeting the human rights obligations codified by the UN Covenants (Coomans 2018: 10; Scheinin 2001: 30; Lempinen 2005: 30; Egan 2013). Monitoring the compliance under the ICESCR and the ICCPR is mainly based on the state reporting system. Optional Protocols do indeed confer the right to individual communication. Still, the Protocol to the ICESCR is not widely ratified and, similar to the state reporting system, does not result in any legally binding or coercive judgments (OHCHR 2020). ${ }^{11}$ On the other hand, IHRL (including the EMS) is enforceable for individuals also in domestic courts at the national level.

How international treaty obtains its legally binding force at the national level depends on a legal approach applied by the state. In a dualist - or pluralist - approach, the state must adopt relevant domestic law to give effect to obligations under the international covenant emphasising the distinction between international law and national legislation (Crawford 2019: 45; Ssenyonjo 2017: 273; Finegan 2011: 478). Contrary to dualism, in monist systems, international law may become part of domestic law and can be directly applied without the need to take further legislative action (Crawford 2019: 45; Ssenyonjo 2017: 283; Finegan 2011: 478). In reality though, and especially in dualistic legal systems, such as in Finland, individuals or even courts seem to very rarely expressly refer to international human rights in domestic courts (CESCR 2014: 6; Hyttinen 2012). Instead, applicants tend to rely on legal provisions that are more tangible to them. Unfortunately, human rights aspects are easily missed when the litigation evolves around national legislation.

Thus, in Finland, the compatibility of the Hospital District's decision on the implementation of legal provisions on the EMS and reducing the ambulances from rural areas was challenged by relying merely on the Health Care Act (Administrative Court of Oulu, 2014). No constitutional references or international

11 In April 2020, only 23 states had ratified the Optional Protocol to the ICESCR and 116 the Protocol to the ICCPR. 
Croatian

International

Relations

Review

$-$

CIRR

$-$

XXVI (87) 2020,

86-119

human rights provisions were invoked, although the facts would have offered ground for such considerations. Lawyers, on the other hand, have little chance of pursuing and succeeding with human rights-based arguments if judges are uneducated or unaware of IHRL. Additionally, health care and the EMS at the national level may too often be regarded as a branch of administrative law, without having any connection either to constitutional or international law (Juskevicius and Balsiené 2010: 98). It is, in fact, questionable as to what extent domestic courts can reasonably be expected to apply human rights deriving from international covenants to the cases concerning out-of-hospital care when the EMS has not expressly been recognised in IHRL.

Notably, human rights protection is more concrete and effective when litigation takes place in close proximity to where the accused violation or non-fulfilment of the obligation occurred. Furthermore, IHRL unequivocally requires states to monitor compliance with human rights obligations and to ensure accountability at the national level (CESCR 1998: 3; Craven 2007: 72; Footer and Rubenstein 2013: 186). Establishing a new General Comment, which lays down a minimum level for the EMS, indicates the resources that should be directed to outof-hospital care, and enlightens the progressive realisation doctrine in relation to the EMS, also offers a more tangible tool for courts and lawyers to deal with the EMS-related claims. Moreover, as the establishment of the judiciary system is one of the main goals of peacebuilding as well (Baker and Obradovic-Wochnik 2016: 286-287; Lapente 2008: 333), a detailed commentary on the EMS would ensure that claims regarding the non-fulfilment of the obligation relating to urgent out-ofhospital care could also be litigated in transitional states.

\section{Concluding remarks}

The EMS has generally been designed to provide urgent treatment for the life-threatening conditions of patients outside medical facilities. Even though the EMS, being a sub-category of the right to health, classically belongs to the second category of human rights, it nevertheless has immense significance in terms of protecting the right to life. Surprisingly, however, the legal provisions of the EMS are somewhat inconsistent during war- and peacetime. 


Croatian
International
Relations
Review
-
CIRR
-
XXVI (87) 2020,
$86-119$

Croatian International Relations
While urgent out-of-hospital medical care is perceived as an essential element of protecting lives during armed conflicts, in peacetime, the EMS faces challenges to be recognised as a valuable human right. The primary cause is the fact that, while Article 12(2)(d) of the International Covenant of Economic, Social and Cultural Rights (ICESCR) is applicable to out-ofhospital care as well, the EMS has not been expressly mentioned in international human rights law (IHRL). Consequently, how legal rules concerning the EMS are implemented, depends on states. This leads to non-harmonised protection.

In order to overcome these challenges and to enhance the protection by the EMS as a human right, the UN Committee of Economic, Social and Cultural Rights (CESCR) should draft a new General Comment specifically dedicated to urgent out-ofhospital care. The CESCR appears as the best instance to draft this new documents because, with Article 12(2)(d) of the ICESCR and the General Comment No. 14, the UN human rights system already has the legal framework applicable to the EMS.

The starting point for the commentary should be to expressly acknowledge the vital connection between the EMS under Article 12(2)(d) of the ICESCR, and the right to life guaranteed by Article 6 of the International Covenant on Civil and Political Rights (ICCPR). Therefore, close co-operation with the UN Human Rights Committee would be beneficiary and highly recommended. Moreover, the General Comment on the EMS should not only cover the standards for an acceptable minimum level of the EMS, reflecting the AAAQ framework and the core obligations enshrined in Article 12 of the ICESCR. Instead, it is equally important to address the variety of resources that need to be directed to out-of-hospital care for states to comply with their obligations under Article 2(1) of the ICESCR. Moreover, the commentary should also enlighten specific steps required to fulfil the progressive realisation of the EMS, as well as measures regarded as prohibited or undesirable retrogressive measures. These guidelines would ensure a more harmonised EMS settings, both in peaceful states and in post-conflict situations, as well as help to assess the situations in which international assistance can be asked and offered, within the scope of fulfilling obligations in relation to the EMS.

Regarding the enforcement, concrete rules would also provide more tangible grounds for lawyers and individuals to argue 
Croatian

International

Relations

Review

$-$

CIRR

$-$

XXVI (87) 2020,

86-119 on human rights terms when challenging public authorities' actions regarding the EMS in domestic courts. Finally, harmonised rules at the universal level would also ensure equal protection available in every country, irrespectively of whether they have just overcome a violent conflict or whether they are regarded as already advanced in the area of human rights protection.

\section{Bibliography}

Administrative Court of Oulu, 2014. Decision. Dnro 01233/12/2299 and 00020/12/2299.

Albarello, F., Crisp, R. and Rubini, M., 2018. Promoting Beliefs in the Inalienability of Human Rights by Attributing Uniquely Human Emotions through Multiple Categorisation. The Journal of Social Psychology, 158(3): 309-321.

Alston, P., 2012. The United Nations: No Hope for Reform?. In the Late Antoine Cassese (ed.). Realising Utopia: The Future of International Law. Oxford: Oxford University Press. pp. 38-51.

Arreola-Risa, C., et al., 2000. Low-cost improvement in prehospital trauma care in Latin American City. Journal of Trauma: Injury, Infection and Critical Care, 48(1):119-24.

Baderin, M. A. and McCorquodale, R., 2007. The International Covenant on Economic, Social and Cultural Rights: Forty Years of Development. In Baderin, M. A. and McCorquodale, R., eds. Economic, Social and Cultural Rights in Action. New York: OUP. pp. 1-24.

Baker, C. and Obradovic-Wochnik, J., 2016. Mapping the Nexus of Transitional Justice and Peacebuilding. Journal of Intervention and Statebuilding, 10(3): 281-301.

Bellamy, A. J. and Williams, P. D., 2015. Trends in Peace Operations, 1947-2013. In Koops, J. A. and MacQueen, N. et al., eds. The Oxford Handbook of United Nations Peacekeeping Operations. Oxford: OUP.

Bethlehem, D., 2013. The Relationship Between International Humanitarian Law and International Human Rights Law in the Situations of Armed Conflict. Cambridge Journal of International and Comparative Law, 2(2): 180-19.

Breitegger, A., 2013. The Legal Framework Applicable to Insecurity and Violence Affecting the Delivery of Health Care in Armed Conflicts and Other Emergencies. International Review of the Red Cross, 95(889): 83-127. 


Croatian
International
Relations
Review
-
CIRR
-
XXVI (87) 2020,
86-119

Croatian International Relations Review

\section{CIRR} 86-119
Broomhill, B., 2003. International Justice \& the International Criminal Court: Between sovereignty and the Rule of Law. New York: OUP.

Buer Haddeland, H., 2019. The Right to Health Care for Irregular Migrants in Norway: Interpretation, Accessibility, and Gaps Between Needs and Rights. Nordic Journal of Human Rights, 37(4): 329-349.

Burkholder, T. W., Hill, K. and Calvello Hynes, E. J., 2019. Developing emergency care systems: a human rights-based approach. Bull World Health Organ, 97(9): 612-619.

Cahill-Ripley, A., 2016. Reclaiming the Peacebuilding Agenda: Economic and Social Rights as a Legal Framework for Building Positive Peace - A Human Security Plus Approach to Peacebuilding. Human Rights Law Review, 16: 223-246.

Chandhoke, N., 2007. Thinking Through Social and Economic Rights. In Bell, D. A. and Coicaud, J-M., eds. Ethics in Action: the Ethical Challenges of International Human Rights NonGovernmental Organization. New York: CUP. pP. 181-197.

Charvet, J. and Kaczynska-Nay, E. 2008. The Liberal Project and Human Rights: The Theory and Practice of a New World Order. Cambridge: CUP.

Committee on Economic, Social and Cultural Rights (CESCR), 1991. General Comment No. 3: The Nature of State Parties' Obligations (Art. 2, para. 1 of the Covenant).

Committee on Economic, Social and Cultural Rights (CESCR). 1998. General Comment No. 9: The Domestic Application of the Covenant.

Committee on Economic, Social and Cultural Rights (CESCR). 2000. General Comment No. 14: The Right to the Highest Attainable Standards of Health (Art. 12 of the International Covenant on Economic, Social and Cultural Rights).

Committee on Economic, Social and Cultural Rights (CESCR), 2014. Concluding observations on the sixth periodic report of Finland. E/C.12/FIN/CO/6.

Committee on Economic, Social and Cultural Rights (CESCR) 2020. General Comment No. 25 on science and economic, social and cultural rights (Article 15 (1) (b), (2), (3) and (4) of the International Covenant on Economic, Social and Cultural Rights).

Coomans, F., 2018. The UN Committee on Economic, Social, and Cultural Rights. In G. Oberleit-ner, ed. International Human Rights Institutions, Tribunals, and Courts. Singapore: Springer. pp. 1-26.

Council of Europe 2020a. Chart of signatures and ratifications 


\section{Croatian \\ International \\ Relations \\ Review \\ $-$ \\ CIRR \\ $-$ \\ XXVI (87) 2020, \\ 86-119}

of Treaty 005: Convention for the Protection of Human Rights and Fundamental Freedoms, [online] 16 October. Available at: https://www.coe.int/en/web/conventions/ full-list/-/conventions/treaty/005/signatures [accessed 16 October 2020].

Council of Europe 2020b. Chart of signatures and ratifications of Treaty 163: European Social Charter (revised), [online] 16 October 2020. Available at: https://www.coe.int/en/web/ conventions/full-list/-/conventions/treaty/163/signatures [accessed 16 October 2020].

Craven, M., 2007. The Violence of Dispossession: Extraterritoriality and Economic, Social and Cultural Rights. In Baderin, M. and McCorquodale, R., eds. Economic, Social and Cultural Rights in Action. Oxford: OUP. pp. 71-88.

Crawford, J., 2019. Brownlie's Principles of Public International Law. Oxford: Oxford University Press.

Easley, C., Marks, S. P. and Morgan Jr., R. E., 2001. The Challenge and Place of International Human Rights in Public Health. American Journal of Public Health, 9(12): 1922-1925.

Egan, S., 2013. Strengthening the United Nations Human Rights Treaty Body System. Human Rights Law Review, 13(2): 209-243.

Evert, L. and Evans, D., 2008. Human Rights. In Arya N. and Santa Barbara, J., eds. Peace Through Health: How Health Professionals Can Work for a Less Violent World. Bloomfield: Kumarian Press. pp. 81-88.

Evju, S., 2009. Should Norway Ratify the Optional Protocol to the ICESCR? - That is the Question. Nordisktidsskrift for Menneskerettigheter, 27(1): 82-90.

Finegan, T., 2011. Neither Dualism nor Monism: Holism and the Relationship between Municipal and International Human Rights Law. Transnational Legal Theory, 2(4): 477-503. FinnHEMS, 2020. FinnHEMSin tutkimus- ja kehitysyksikön julkaisuja, [online]. Available at: https://finnhems.fi/ julkaisuja/ [accessed 14 October 2020].

Footer, K. H. A. and Rubenstein, L. S., 2013. A Human Rights Approach to Health Care in Conflict. International Review of the Red Cross, 95(889): 167-187.

Frankenberg, G., 2014. Human Rights and the Belief in a Just World. International Journal of Constitutional Law, 12(1): 35-60. Geneva Convention (I) for the Amelioration of the Condition of the Wounded and Sick in Armed Forces in the Field. Geneva, 12 August 1949.

Geneva Convention (II) for the Amelioration of the Condition of 


Croatian
International
Relations
Review
-
CIRR
-
XXVI (87) 2020,
86-119

Croatian International Relations Review 86-119
Wounded, Sick and Shipwrecked Members of Armed Forces at Sea. Geneva, 12 August 1949.

Geneva Convention (III) relative to the treatment of Prisoners of War. Geneva, 12 August 1949.

Geneva Convention (IV) relative to Protection Civilian Persons in Times of War. Geneva, 12 August 1949.

Gilbert, S. K., Wen, L. S. and Pines, J. M., 2017. A comparison of perspectives on costs in emergency care among emergency department patients and residents. World Journal on Emergency Medicine, 8(1): 39-42.

Greenwood, C., 2006. The Law of War (International Humanitarian Law). In Evans, M. D., ed. International Law. New York: OUP. pp. 738-815.

Gutlove, P., 2007. Health Bridges for Peace: Integrating Health Care with Community Reconciliation. Medicine, Conflict and Survival, 14(1): 6-23.

Hoffman, K. A. and Mancini, M., 2017. Emergency Health Care Professionals' Understanding of the Costs of Care in the Emergency Department. The Journal of American Osteopathic Association, 117(6): 359-364.

Hoikka, M., ert al., 2016. Medical priority dispatch codescomparison with National Early Warning Score. Scandinavian Journal of Trauma, Resuscitation and Emergency Medicine, 24(142).

Hoikka, M., Silfvast, T. and Ala-Kokko, T. I., 2017. A high proportion of prehospital emergency patients are not transported by ambulance: a retrospective cohort study in Northern Finland. Acta Anaesthesiologica Scandinavica, 61(5): 549-556.

Human Rights Committee (HRC), 1982. General Comment No. 6.: Art. 6 (Right to Life).

Human Rights Committee (HRC), 1992. General Comment No 20.: Art. 7 (Prohibition of Torture, or Other Cruel, Inhuman or Degrading Treatment or Punishment).

Hunt, P., 2007. Right to the highest attainable standard of health. Lancet, 370(9585): 369-371.

Hunt, P. and Backman, G., 2008. Health Systems and the Right to the Highest Attainable Standard of Health. Health and Human Rights, 10(1): 81-92.

Hunt, P., 2016. Interpreting the International Right to Health in a Human-Rights-Based Approach to Health. Health and Human Rights Journal, [online] 3 December. Available at: https://www.hhrjournal.org/2016/12/interpreting-theinternational-right-to-health-in-a-human-rights-based- 


\author{
Croatian \\ International \\ Relations \\ Review \\ $-$ \\ CIRR \\ $-$ \\ XXVI (87) 2020, \\ 86-119
}

approach-to-health/ [accessed 17 March 2020].

Hyttinen, S., 2012. Sosiaaliset ihmisoikeudet ja suomalaiset tuomioistuimet - otetaanko sosiaaliset ihmisoikeudet vakavasti?. Oikeus 4.

International Committee of the Red Cross (ICRC), 2003. National Enforcement of International Humanitarian Law. Geneva.

International Committee of the Red Cross (ICRC), 2014. Health Care and Violence: The Need for Effective Protection. New York. International Committee of the Red Cross (ICRC), 2016. Protecting Health Care: Key Recommendations. Geneva.

International Court of Justice (ICJ), 1949. Corfu Channel Case. Judgment.

International Court of Justice (ICJ), 1996. Legality of the Threat or Use of Nuclear Weapons. Advisory Opinion.

International Court of Justice (ICJ), 2004. Legal Consequences of the Construction of the Wall in Occupied Palestinian Territory. Advisory Opinion.

International Peace Institute (IPI), 2013. Taking Stock, Moving Forward: Report to Foreign Ministry of Finland on the 2012 Elections to the United Nations Security Council.

Juskevicius, J. and Balsiené, J., 2010. Human Right in Health Care: Some Remarks on the Limits of the Right to Health Care. Jurisprudencia, 4(122): 95-110.

Kandelman, D., et al., 2012. Oral health care systems in developing and developed countries. Periodontologr, 60(1): 98-109.

Kerikmäe, T., Hamulak, O. and Chochia, A., 2016. A Historical Study of Contemporary Human Rights: Deviation or Extinction?. Acta Baltica Historiae et Philosophiae Scientiarum, 4(2): 98-115.

Kerikmäe, T. and Nyman-Metcalf, K., 2012. Less is More or More is More? Revisiting Universality of Human Rights. International and Comparative Law Review, 12(1): 39-56.

Kobusingye, O. C., et al., 2005. Emergency Medical System in Low- and Middle-Income Income Countries: Recommendations for Actions. Bulletin of the World Health Organization, 83(3): 626-631.

Kosonen, A., et al., 2016. Oireista työdiagnoosiin. Helsinki: Sanoma Pro.

Kuisma, M. et al., 2019. Quality and patient safety in emergency medical services and hospital emergency department services - from planning to implementation and evaluation. Helsinki: Publications of the Ministry of Social Affairs and Health 2019: 23. 


Croatian
International
Relations
Review
-
CIRR
-
XXVI (87) 2020,
86-119

Croatian International Relations Review 86-119
Lai, T. et al., 2013. Estonia: Health System Review. Health System in Transition, 15(6): 1-196.

Laplente, L. J., 2008. Transitional Justice and Peace Building: Diagnosing and Addressing the Socio-economic Roots of Violence through a Human Rights Framework. The International Journal of Transitional Justice, 2(3): 331-355.

Lempinen, M., 2005. The United Nations Commission on Human Rights and the Different Treatment of Governments: An Inseparable Part of Promoting and Encouraging Respect for Human Rights? In Gayim, E., Leino, P., and Lempinen, M., eds. Human Rights and Institutional Politics: The EU, UN and Other International Institutions. Helsinki: Erik Castrén Institute of International Law and Human Rights. pp. 29-44.

Lubell, N. and Prud'homme, N. 2016. Impact of Human Rights Law. In Liivoja, R. and McCormack, T., eds. Routledge Handbook of the Law of Armed Conflict. London: Routledge. pp. 106-120.

MacDougall, H., 2017. Humans, Hierarchy, and Human Rights. National Lawpers' Guild Review 74: 129-146.

MacNaughton, G. and P. Hunt, 2009. Health impact assessment: The contribution of the right to the highest attainable standard of health. Public Health, 123: 302-305.

Martin, F. F., 2006. International Human Rights \& Humanitarian Law: Treaties, Cases \& Analysis. New York: CUP.

Mehmood, A., Rowther, A. A., Kobusingye, O. and Hyder, A. A. (2018). Assessment of pre-hospital emergency medical services in low-income settings using a health systems approach. International Journal of Emergency Medicine, 11(53).

Montgomery, J. D., 2002. Is There a Hierarchy of Human Rights?. Journal of Human Rights, 1(3): 373-385.

Müller, A., 2013. The Relationship between Economic, Social and Cultural Rights and International Humanitarian Law: An Analysis of Health-Related Issues in Non-International Armed Conflicts. Leiden: Martinus-Nijhoff Publishers.

Naicker, S., et al., 2009. Shortage of Healthcare Workers in Developing Countries - Africa. Ethnicity \& Disease, 19: 60-64. Niemelä, P., 2005. The Politics of Responsibility to Protect:

Problems and Prospects. Helsinki: Erik Castrén Institute of International Law and Human Rights.

Nissen, A., 2018. A Right to Access to Emergency Health Care: The European Court of Human Rights Pushes the Envelope. Medical Law Review, 26(4): 693-702.

Nye, J. S., 2005. Understanding International Conflicts: An 


Croatian
International
Relations
Review
-
CIRR
-
XXVI (87) 2020,
$86-119$

Introduction to Theory and History. New York, Pearson. Optional Protocol to the International Covenant on Civil and Political Rights. 1966.

Optional Protocol to the International Covenant on Economic, Social and Cultural Rights. 2008.

Parliamentary Ombudsman of Finland, 2015. En Jämlik Tillgänglighet av Läkarhelikoptrar. Dnr 1989/4/14.

Parliamentary Ombudsman of Finland. 2017. Lääkärihelikopteritoiminnan ulottaminen Lapin Alueelle Turvaisi Yhdenvertaisuutta Nүkpistä Paremmin. Dnro 1016/4/16.

Paulin, J., et al., 2020. Changing role of EMS - analyses of nonconveyed and conveyed patients in Finland. Scandinavian Journal of Trauma, Resuscitation and Emergency Medicine, 28(45).

Perkins, G. D. et al., 2015. European Resuscitation Council Guidelines for Resuscitation 2015: Adult Basic Life Support and Automated External Defibrillation. Resuscitation, 95(81): 81-99.

Protocol Additional to the Geneva Conventions of 12 August 1949, and relating to the Protection of Victims of International Armed Conflicts (Protocol I), 8 June 1977.

Protocol Additional to the Geneva Conventions of 12 August 1949, and Relating to the Protection of Victims of Non-International Armed Conflicts (Protocol II), 8 June 1977.

Ramcharan, B. G., 2008. Preventative Diplomacy at the UN. Indiana: IUP.

Razzak, J. A. and Kellermann, A. L., 2002. Emergency medical care in developing countries: is it worthwhile? Bulletin of the World Health Organization, 80(11): 900-905.

Report of the Special Rapporteur on the right of everyone to the enjopment of the highest attainable standard of physical and mental health, Report on Health in conflict, 2013. A/68/297

Reynolds, T. A., et al., 2018. Strengthening health systems to provide emergency care. Annex 13A: WHO Emergency Care Systems Framework. In: Jamison, D. T, et al., eds. Disease control priorities: improving health and reducing povertp. Washington, DC: World Bank.

Roach, K., 2008. The Challenges of Crafting Remedies for Violations of Socio-economic Rights. In Langford, M. ed. Social Rights Jurisprudence: Emerging Trends in International and Comparative Law. New York: CUP. PP. 46-58.

Roberts, A. and Cuelff, R., 2010. Documents on the Laws of War. New York: OUP. 


Croatian
International
Relations
Review
-
CIRR
-
XXVI (87) 2020,
86-119

Croatian International Relations 86-119
Roivainen, P., et al., 2020. Telephone triage performed by nurses reduces non urgent ambulance missions: A prospective observational pilot study in Finland. Aneasthesiologica Scandinavia, 64(4): 556-563.

Roth, R., 2007. Defending Economic, Social and Cultural Rights: Practical Issues Faces by an International Human Rights Organization. In Bell, D. A. and Coicaud, J-M., eds. Ethics in Action: the Ethical Challenges of International Human Rights Non-Governmental Organization. New York: CUP. pp. 169-180. Rubenstein, L. S., 2013. A Way Forward in Protecting Health Services in Conflict: Moving Beyond the Humanitarian Paradigm. International Review of the Red Cross, 95(889): 331-340.

Salminen-Tuomaala, M., et al., 2018. Emergency patients' and family members' experiences of encountering care providers and receiving care in nonconveyance situations. Scandinavian journal of caring sciences, 32(4): 1371-1378.

Santa Barbara, J., 2008. Analyzing Peace through Health. In Arya, N. and Santa Barbara, J., eds. Peace through Health: How Health Professionals Can Work for a Less Violent World? Bloomfield: Kuarian Press. pp. 119-130.

Sarapuu, K. and Lember, V., 2015. Coordination through Contracting: Experience with Estonia:

Out-of-Hospital Emergency Medical Medicine. Public Management Review, 17(7): 1021-1030.

Scheinin, M., 2001. Economic and Social Rights as Legal Rights. In Asbjørn, E., Krause, C. and Rosas, A., eds. Economic, Social and Cultural Rights: A Textbook. Dordrecht: Martinus Nijhoff Publishers. pp. 29-54.

Silfvast, T., et al., 2013. Ensihoito-opas. Helsinki: Duedecim. Skogly, S. I. and Gibney, M. 2002. Transitional Human Rights Obligations. Human Rights Quarterly, 24: 781-798.

Skogly, S. 2012. The Requirement of Using the 'Maximum of Available Resources' for Human Rights Realisation: A Question of Quality as well as Quantity?. Human Rights Law Review, 12(3): 393-420.

Sosiaali - ja terveysministeriö (STM; i.e. Ministry of Social Affairs and Health) 2017. Sosiaali - ja tervepsministeriön asetus ensihoitopalvelusta: muistio.

Sosiaali- ja terveysministeriö (STM, i.e. Ministry of Social Affairs and Health), 2018. Ensihoidon Ilmailupalveluita Kehittävän Työryhmän Loppuraportti.

Spear, J., 2000. Disarmament and Demobilisation. In Stedman, S. J., Rotchild, D., and Cousens, E. M., eds. Ending Civil Wars: 


\section{Croatian International Relations Review \\ - \\ CIRR \\ - \\ XXVI (87) 2020, 86-119}

The Implementation of Peace Agreements. London: LynneRienne Publishers. pp. 141-181.

Ssenyonjo, M., 2017. The Influence of the International Covenant on Economic, Social and Cul-tural Rights in Africa. Netherlands International Law Review, 64: 259-289. Terveydenhuoltolaki (Health Care Act [of Finland]). 1326/2010. Tervishoiuteenuste korraldamise seadus (Health Service Organisation Act [of Estonia]). RT I 2001, 50, 284). The 1864 Convention for the Amelioration of the Condition of the Wounded in Armies in the Field.

The 1868 Declaration Renouncing the Use, in Time of War, of Explosive Projectiles Under 400 Grammes Weight.

Toebes, B., 2015. Human Rights and Public Health: Towards a Balanced Relationship. The International Journal of Human Rights, 19(4): 488-504.

United Nations Human Rights Office of the High Commissioner (OHCHR). 2020. Status of Ratification, Interactive Dashboard, [online] 17 March. Accessible at: http://indicators.ohchr.org/ . [accessed 17 March 2020]. United Nations (UN), 2008. United Nations Peacekeeping Operations: Principles and Guidelines. New York.

United Nations, 2010. UN Peacebuilding: An Operation, UN Peacebuilding Support Office, [online]. Available at http:// www.un.org/en/peacebuilding/pbso/pdf/peacebuilding_ orientation.pdf [accessed 12 March 2018].

Uusitalo, J., 2018a. From Legislative Shortcomings towards Better Protection of Human Rights - Analysis of Legislation on the Emergency Medical Service in Finland and Estonia. European Journal of Health Law, 25(4): 389-406. Uusitalo, J., 2018b. Responsibility to Protect and Human Security: Doctrines Destroying or Strengthening Sovereignty?. International and Comparative Law Review, 18(1): 89-103.

Uusitalo, J, 2018c. Protecting the Right to Emergency Medical Service in the European Court of Human Rights and Collective Complaint Procedure. Baltic Journal of Law and Politics, 11(1): 48-84.

Vienna Declaration and Programme for Actions, 1993. World Conference on Human Rights.

Warren, K., 2007. The 2000 UN Human Trafficking Protocol: Rights, Enforcement, Vulnerabili-ties. In Goodale, M. and Engle Merry, S. (eds.). The Practice of Human Rights: Tracking Law be-tween the Global and the Local. Cambridge: Cambridge University Press. pp. 242-269. 


$\begin{array}{ll}\begin{array}{l}\text { Croatian } \\ \text { International } \\ \text { Relations } \\ \text { Review }\end{array} & \text { White, N. D., 2015. Peacekeeping and International Law. In } \\ - & \text { Koops, J. A. and MacQueen, N. et al, eds. The Oxford Handbook } \\ \text { cIRR } & \text { of United Nations Peacekeeping Operations. Oxford: OUP. } \\ - & \text { Woodward, S. L., 2000. Economic Priorities for Successful Peace } \\ \text { XxVI (87) 2020, } & \text { Implementation. In Stedman S. J. et al., eds. Ending Civil } \\ 86-119 & \text { Wars: The Implementation of Peace Agreements. London: Lynne } \\ & \text { Rienne Publishers. Pp. 183-214. } \\ \text { World Health Organization (WHO), 2019a. Emergency care } \\ \text { systems framework infographic. Geneva: World Health } \\ \text { Organization. Available at: https://www.who.int/ } \\ \text { emergencycare/emergencycare_infographic/en/ [accessed } \\ \text { 7 October 2020]. } \\ \text { World Health Organization (WHO), 2019b. Emergency and } \\ \text { trauma care. Emergency care systems for universal health } \\ \text { coverage: ensuring timely care for the acutely ill and } \\ \text { insured. A72/31. } \\ \text { Young, K., 2008. The Minimum Core of Economic and Social } \\ \text { Rights: A Concept in Search of Content. The Yale Journal of } \\ \text { International Law, 33: 112-175. } \\ \text { Zaidi, S., 2010. Millennium Development Goal 6 and the Right } \\ \text { to Health: Conflictual or Contemporary?. International } \\ \text { journal of Human Rights, 7(12): 123-143. } \\ \text { Zyber, G., 2018. Enforcement of International Humanitarian } \\ \text { Law. In Oberleitner, G., ed., International Human Rights } \\ \text { Institutions, Tribunals, and Courts. Singapore: Springer. pp. } \\ \text { 1-24. }\end{array}$

